\title{
An efficient micro-method of DNA isolation from mature leaves of four hardwood tree species Acer, Fraxinus, Prunus and Quercus
}

\author{
François Lefort ${ }^{*}, \mathrm{ab}$, Gerard. C. Douglas ${ }^{\mathrm{a}}$ \\ ${ }^{a}$ Teagasc, Food and Agriculture Development Authority, Kinsealy Research Centre, Malahide Road, Dublin 17, Ireland \\ ${ }^{b}$ Laboratory of Plant Physiology and Biotechnology, Department of Biology, University of Crete,
} P.O. Box 208, 71409 Heraklio, Greece

(Received 5 January 1998; accepted 1 October 1998)

\begin{abstract}
It is difficult to purify DNA from mature tree leaves at the end of the growing season, because of their thick cell wall, and high content in polysaccharides, phenolic compounds and endonucleases. A simple, fast and efficient method for DNA purification from $100 \mathrm{mg}$ fresh weight leaf samples is described here. It has been developed for extracting DNA from mature leaves of Quercus, Fraxinus Prunus and Acer. The protocol is a modified CTAB (hexadecyltrimethylammonium bromide) method including a combination of $\beta$-mercaptoethanol, polyvinylpyrrolidone, sodium dodecyl sulfate and lithium chloride including short centrifugation runs. It is very efficient yielding up to $950 \mu \mathrm{g} \mathrm{DNA} / \mathrm{g}$ of fresh weight, even when very mature leaves are processed. The extracted DNA was used as template to characterise oaks by microsatellite analysis. Its efficiency has been compared to four commercially available kits and two other published. CTAB protocols. The protocol is also inexpensive compared to commercial kits. (@ Inra/Elsevier, Paris.)
\end{abstract}

\section{Acer / DNA purification / Fraxinus / Prunus / Quercus}

Résumé - Une micro-méthode d'extraction d'ADN à partir de feuilles matures de quatre espèces d'arbres forestiers Acer, Fraxinus, Prunus et Quercus. Il est difficile de purifier l'ADN de feuilles d'arbres à maturité et spécialement à la fin de la période de croissance c'est-à-dire en automne, pour plusieurs raisons, telles que de fortes concentrations de polysaccharides, de composés phénoliques et d'endonucléases ainsi que des parois cellulaires épaisses. Nous décrivons une micro-méthode efficace et rapide permettant de purifier de l'ADN à partir de $100 \mathrm{mg}$ de poids frais de feuilles à maturité des espèces d'arbres suivantes : Quercus robur, $Q$. petraea, Fraxinus excelsior, Prunus avium et Acer pseudoplatanus. Le protocole est basé sur l'utilisation de bromure d'hexadécyltriméthylammonium (CTAB) combiné a l'emploi de $\beta$-mercaptoéthanol, de polyvinylpyrrolidone, de sodium dodécyl sulfate et de chlorure de lithium. Cette micro-méthode permet d'obtenir jusqu'à $950 \mu \mathrm{g}$ DNA / g de poids frais. L'ADN, extrait d'une variété de matériels végétaux (culture in vitro, matériel de serre ou prélevés en forêt) par cette méthode, est de la qualité nécessaire aux techniques de biologie moléculaire (digestion enzymatique, clonage ou amplification par la réaction de la polymérase en chaine (PCR) de marqueurs microsatellites). Son efficacité comparée à celle de quatre protocoles commercialisés et deux autres protocoles basés sur l'emploi de CTAB est supérieure en rendement et qualité. Ce protocole a enfin l'avantage d'être bon marché par rapport aux protocles commerciaux. (@ Inra/Elsevier, Paris.)

Acer / ADN / Fraxinus / Prunus / Quercus

* Correspondence and reprints

flefort@biology.uch.gr. 


\section{INTRODUCTION}

Plant breeding and genetic identification have until recently relied only on phenotype analysis (either by direct phenotype assessment, or by analysis of varied isoenzymes systems). Because phenotypic traits are affected by many factors, it can be a valuable method to assess polymorphic variation. The appearance of molecular genetic techniques such RFLP (restriction fragment length polymorphism) and then RAPD (random amplified polymorphic DNA)-PCR offers a direct access to the DNA level. Furthermore, microsatellites sequences are becoming available for an increasing number of plant and tree species. Microsatellite PCR offers a reliable method to assess DNA polymorphism of numerous individuals within a species and among species of a same genus.

However, all these molecular techniques require the availability of DNA in sufficient quantity and of good quality and purity.

Although several different extraction methods have been published for herbaceous plants and trees $[1-4,8$, $11-13]$ and are even available as commercial kits, protocols are either too long, involve excessive volumes of extraction buffer, are only efficient for a range of species or for one type of plant material. Last but not least, most of the protocols are simply not efficient for difficult material. Many protocols may provide DNA when processing in vitro material or young leaves of herbaceous plants and trees; however, they may be unsuitable for extracting DNA from mature or dry leaves. DNA fingerprinting means that a great number of samples have to be processed, thus the DNA purification protocol must be fast and easy to standardise in order to extract numerous samples in a workday.

After having tested a number of commercial kits and published methods for DNA extraction on the different trees we are working with, we developed a protocol to extract DNA from mature leaves harvested in October, from four hardwood tree species: Quercus, Fraxinus, Prunus and Acer.

\section{MATERIAL AND METHODS}

\subsection{Plant material}

Fresh mature leaves were collected in October from grafted elite clones of Quercus robur, $Q$. petraea, Fraxinus excelsior, Prunus avium and Acer pseudoplatanus. Plants were grown in the glasshouse, outdoors (field, arboretum) and in some cases leaves from in vitro stocks were also used.

\subsection{DNA purification}

One hundred milligrams of fresh plant material (leaf) was ground in liquid nitrogen using a ceramic mortar and pestle to give a green powder. The powder was transferred to a new $1.5 \mathrm{~mL}$ polypropylene tube using a spatula. At this time, $1 \mathrm{~mL}$ of DNA extraction buffer [ 50 $\mathrm{mM}$ Tris- $\mathrm{HCl} \mathrm{pH} 8.0,20 \mathrm{mM}$ EDTA pH 8.0, $0.7 \mathrm{M}$ $\mathrm{NaCl}, 0.4 \mathrm{M} \mathrm{LiCl}, 1 \% \mathrm{w} / \mathrm{v} \mathrm{CTAB}$ (hexadecyltrimethylammonium bromide), $1 \% \mathrm{w} / \mathrm{v}$ PVP $40,2 \% \mathrm{w} / \mathrm{v}$ SDS] and $10 \mu \mathrm{L}$ of $\beta$-mercaptoethanol (1 \% final concentration) were added. The mixture was vortexed for $5 \mathrm{~s}$, mixed by $2-3$ inversion and then incubated for $15 \mathrm{~min}$ at $65^{\circ} \mathrm{C}$ in a water-bath.

After addition of the powdered leaf material and immersion in the $65{ }^{\circ} \mathrm{C}$ water bath, the mixture became clear in a few seconds, as soon as the different reagents interacted with proteins, phenolic compounds and polysaccharides.

After incubation, $0.5 \mathrm{~mL}$ of chloroform/isoamylalcohol (24:1) was added to the tube, the mixture was agitated thoroughly until making an emulsion and centrifuged $1-5 \mathrm{~min}$ in a microfuge at $17000 \mathrm{~g}(14000 \mathrm{rpm}$ in an ALC microcentrifugette 4214 rotor A-12). The aqueous phase was transferred to a new $1.5 \mathrm{~mL}$ tube and centrifuged $1 \mathrm{~min}$ at $17000 \mathrm{~g}$ in order to pellet possible debris. The supernatant was then transferred to a new tube and an equivalent volume of isopropanol was added to the aqueous solution. The tube was swirled gently and a white DNA precipitate appeared. The tube was then centrifuged 1 min at $17000 \mathrm{~g}$ and the supernatant was withdrawn. The DNA pellet was washed with $1 \mathrm{~mL}$ $70 \%$ ethanol, centrifuged for $1 \mathrm{~min}$ at $17000 \mathrm{~g}$. Finally the supernatant was withdrawn and the pellets allowed to dry on the bench for $10 \mathrm{~min}$. DNA pellets were resuspended in $50-100 \mu \mathrm{L}$ of $10 \mathrm{mM}$ Tris- $\mathrm{HCl} \mathrm{pH} 8.0,1 \mathrm{mM}$ EDTA. As the solution contained RNA and DNA, the protocol was followed by a RNase digestion to remove RNAs. RNA digestion was performed by adding $2 \mu \mathrm{L}$ of RNase $\left(0.5 \mathrm{mg} \mathrm{mL}^{-1}\right)$ (Boehringer Mannheim, UK) and incubating for $30 \mathrm{~min}$ at $37^{\circ} \mathrm{C}$.

Although the resulting DNA mixture could be directly used after RNase digestion in amplification experiments, it also could be ultimately purified through a column such as the Wizard Clean-up System (Promega Biotec, Madison, WI, USA).

While developing this protocol we also tested four commercial kits (DNA Isolator, Genosys, UK: Nucleon Phytopure, Scotlab, UK; Snap-O-Sol Biotexc, USA and Xtract, AMS Biotechnologies, USA) and two modified CTAB protocols $[4,13]$. The Nucleon Phytopure kit and the two published protocols were specifically designed for plant material. 


\subsection{DNA analysis}

DNA concentration was given by absorbance reading at $260 \mathrm{~nm}$ and $280 \mathrm{~nm}$ in a UV spectrophotometer. Purity was estimated by the OD260/OD280 ratio. DNA quantities were also confirmed by estimation after ethidium bromide staining viewed under UV light on $1 \%$ agarose gels gel in 1X Tris Borate EDTA (TBE) buffer. Samples were run along with four known quantities $(0.1$, $0.25,0.5$ and $1 \mu \mathrm{g}$ ) of uncut $\lambda$ DNA (Promega, USA). DNA quality was also estimated on the same gels.

\subsection{DNA digestion}

DNA was digested by Hind III restriction enzyme (Stratagene, Cambridge, UK) according to the manufacturer's recommendations.

\subsection{Microsatellite PCR amplification}

We used flanking primers for the microsatellite locus AG110 (EMBL accession X84082) which has been described by Steinkellner et al. [9].

The reaction volume was $50 \mu \mathrm{L}$ and included $20 \mathrm{mM}$ Tris-Hcl pH 8.3, $50 \mathrm{mM} \mathrm{KCl}, 1.5 \mathrm{mM} \mathrm{MgCl}, 62.5 \mu \mathrm{M}$ dNTPs each (Biofinex, Praroman, Switzerland), $1 \mu \mathrm{M}$ forward primer [5'-ggaggcttccttcaacctact], $1 \mu \mathrm{M}$ reverse primer [5'-gatctcttgtgtgctgtattt], 1,5 unit AmpliTaq polymerase (Perkin Elmer, Foster City, CA, USA) and approximately $50 \mathrm{ng}$ DNA template. A $5 \mathrm{~min}$ initial denaturation at $94{ }^{\circ} \mathrm{C}$ was followed by 35 cycles $\left(50{ }^{\circ} \mathrm{C}\right.$ for $1 \mathrm{~min}, 72^{\circ} \mathrm{C}$ for $30 \mathrm{~s}, 92^{\circ} \mathrm{C}$ for $1 \mathrm{~min}$ ) terminated by an $8 \mathrm{~min}$ final extension at $72{ }^{\circ} \mathrm{C}$. PCR products were checked on a $1 \%$ agarose gel in $1 \times \mathrm{TBE}$ and then analysed on a denaturant sequencing gel (Cast Away gel $6 \%$ polyacrylamide) run in a CastAway Sequencing System (Statagene, La Jolla, USA). Gels were run for $2 \mathrm{~h}$ at $1500 \mathrm{~V}$, and then silver stained according to a modified silver staining protocol [10].

Lengths in base pairs of microsatellites PCR products were estimated by running a pBR 322 plasmid digested by Hae III (Biofinex) and a pUC plasmid digested by MspI (Biofinex) as base pair length ladders.

\section{RESULTS AND DISCUSSION}

This protocol is a modification of the original CTAB protocol of Doyle and Doyle [2] and other CTAB methods designed for extraction of DNA from plant material $[1,3,4,7,8,12])$. CTAB (1-2\%) extraction buffers are often made up in Tris- $\mathrm{HCl}(0.05-0.1 \mathrm{mM})$ buffer in a $\mathrm{pH}$ range $8.0-9.5$, containing EDTA $(5-50 \mathrm{mM}), \mathrm{NaCl}$ $(1.25-1.5 \mathrm{M})$. They also often include polyvinylpyrrolidone (PVP 40000 up to 360000 ) and a variety of reductants (DTT, ascorbic acid, $\beta$-mercaptoethanol). PVP and reductants are used to avoid the formation of insoluble complexes between phenolic substances and DNA. CTAB is a cationic detergent which disrupts membranes and may also complex DNA when $\mathrm{NaCl}$ concentration is lower than $0.7 \mathrm{M}$ It is also sometimes replaced by sodium dodecyl sulfate, also a cationic detergent which is known to complex with proteins and confer on them a negative charge. We used here both detergents in combination with a decreased $\mathrm{NaCl}$ concentration at the limit at which CTAB complexes with DNA. We initially used very high concentrations of $\mathrm{LiCl}$ in order obtain a selective precipitation of RNAs. These trials did not achieve the expected results but it was observed that total nucleic acid yields were increased. After different trials we kept $\mathrm{LiCl}$ at a concentration of $0.4 \mathrm{M}$.

The improvement in DNA yield could maybe be explained by the electrostatic interactions between the different chemicals, nucleic acids and proteins. This combination of chemicals seems to prevent more efficiently formation of insoluble complexes of DNA than the classical combination of one detergent, one reductant, one salt offered by other protocols.

We found a final concentration of $1 \% \beta$-mercaptoethanol to be optimal in order to keep the nucleic acids in a non-oxidative environment and to denature endonucleases activities. Freezing leaf samples in liquid nitrogen facilitated cell breakage by grinding since mature leaves of trees are very tough and other methods of homogenisation that we tested were less successful. Grinding in liquid nitrogen provides a non-oxidative environment that may avoid oxidation of phenolic compounds present in older leaves during homogenisation of the tissue. This protocol resulted in white DNA pellets easily solubilised in TE buffer. Figure 1 shows DNA and Hind III digested DNA from mature leaves of each of the four species. RNA was removed by RNase digestion. This protocol gave good quality DNA of a size somewhat above $21 \mathrm{~kb}$. Another advantage of this protocol is the small volume of extraction buffer enabling all steps to be performed in a $1.5 \mathrm{~mL}$ Eppendorf type tube, reducing useless handling.

The time required for a single extraction was about $40 \mathrm{~min}$ from the beginning to the resuspension in TE buffer and it was easy to process a large number of samples in a workday. The most laborious step is the grinding step and if numerous samples are extracted, they may be kept on ice or in freezer $\left(-20^{\circ} \mathrm{C}\right)$ until going on with the $65{ }^{\circ} \mathrm{C}$ incubation step for all samples. The grinding 


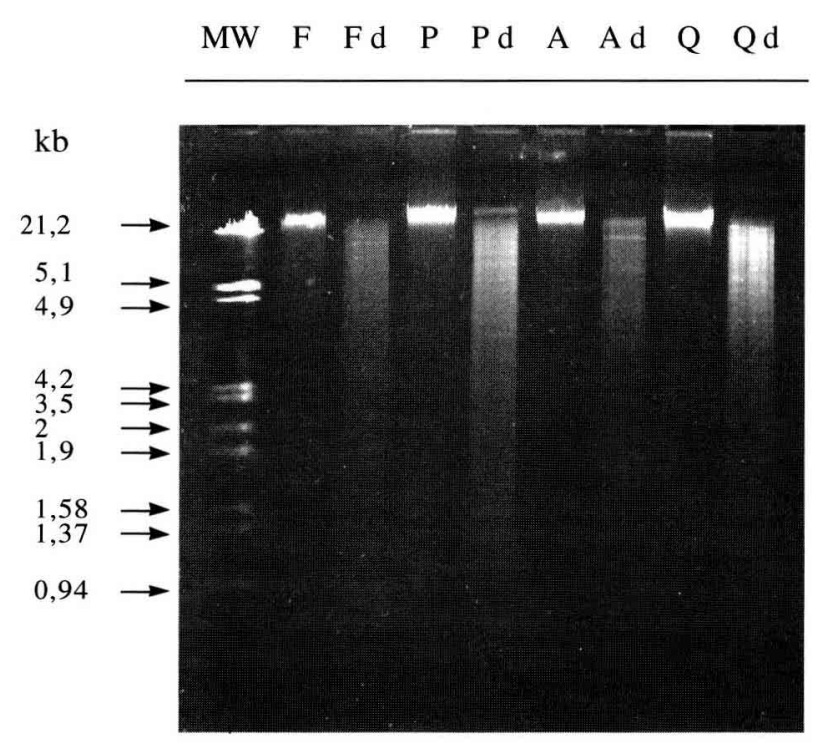

Figure 1. Restriction enzyme (Hind III) digestion of genomic DNA extracted from mature leaves of different tree species. MW: molecular weight markers (Eco RI/Hind III cut ( DNA); F: Fraxinus DNA; Fd; Fraxinus DNA digested with Hind III; P: Prunus DNA; Pd: Prunus DNA digested with Hind III; A: Acer DNA; Ad: Acer DNA digested with Hind III; Q: Quercus DNA; Qd: Quercus DNAS digested with Hind III.

step could be optimised with the use of automated grinders. This protocol might also be used to obtain RNA if DNase digestion is undertaken.

The protocol described above was used to extract DNA from 20 clones of Quercus, 15 clones of Fraxinus, 16 clones of Prunus and 15 clones of Acer. For oak, the yield of DNA ranged from 200 to $950 \mu \mathrm{g}$ DNA per $g$ fresh weight per clone and for the three other species the yields ranged from 350 to $950 \mu \mathrm{g}$ DNA per $\mathrm{g}$ fresh weight. OD260/OD280 ratios were 1.70-1.95.

Comparisons between this modified CTAB protocol and other tested methods are given in table I. Among the four commercial kits tested, only the Nucleon Phytopure kit yielded DNA but only from in vitro culture and not from other sources of plant material. The method of Sul and Korban [12] was originally designed for extracting DNA from in vitro cultures of apple tree, Italian stone pine, rose and tobacco. Applied to plant material of the four species studied, it only yielded degraded DNA except for in vitro material. Only the method of Graham et al. [3] yielded good quality DNA for all kind of plant material but in very poor amounts.

Microsatellite polymorphisms of 17 elite clones of oak obtained by amplification of the microsatellite locus

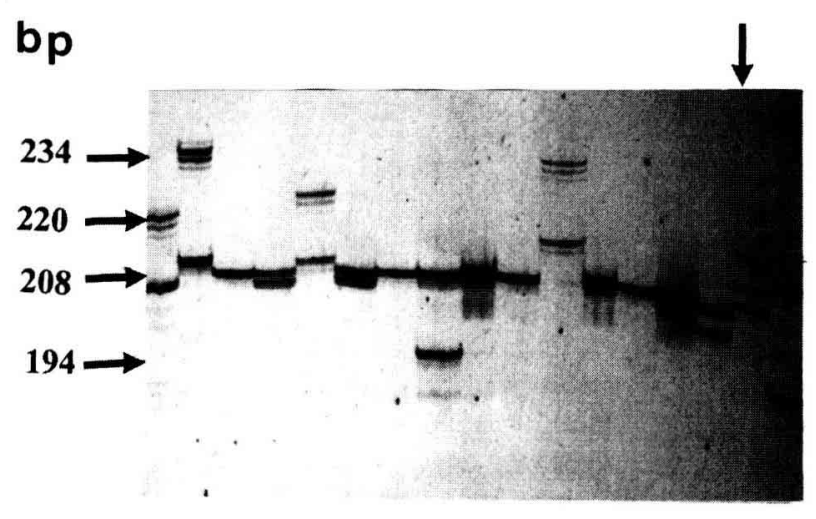

Figure 2. Amplification of the microsatellite locus AG 110. The trees analysed on this gel are designated from left to right as: TN3 (Tullynally 3), TN6 (Tullynally 6), TN7 (Tullynally 7), MB25 (Mount Bellew 25), L21 (Lavagh 21), B9 (Bree 9), TN4 (Tullynally 4), TN11 (Tullynally 11), D33 (Donadea 33), MB26 (Mount Bellew 26), B6 (Bramwald 6), T6 (Thomastown 6), PP (Phoenix Park), 135, A44 (Allen 44), D91 (Dundrum 91), K79 (Knocktopher 71).

AG110 [9] are shown in figure 2. As shown in figure 2, either a two-band profile was recorded when the tree was heterozygous at this locus, or a one-band profile when the tree was homozygous at this locus. Unexpectedly one tree Dundrum 91 gave a three-band profile, where a two band pattern was expected (figure 2, arrow). This could be explained by several hypotheses: this tree could be a triploid, a trisomican aneuploidy, with one extra chromosome, or the pattern obtained could be an artefact of the method.

In conclusion, the protocol described provided DNA of good quality by a quick method of extraction from tree species which have often been a problem regarding extraction of their DNA. DNA yields from a $0.1 \mathrm{~g}$ sample are sufficient for PCR and RFLP purposes.

It gave consistent and reliable results for all sources of plant material, that is to say from in vitro cultures, from green house and in the field grown trees. DNA quality is suitable for DNA amplification as shown by microsatellite amplification in oak and current work on Vitis vinifera (unpublished results), and also for molecular cloning Lefort et al. [6]. This protocol has also been used with dry leaves of oak [5], dry leaves and buds of several Fraxinus species (Dr N. Frascaria, ENGREF, Paris, France; pers. comm.), seeds of Acacia mangium and Acacia crassicarpa, young and expanded leaves and chloroplast enriched fractions of Vitis vinifera from the vineyard (unpublished results). 
Table I. Comparison of seven methods of DNA extraction applied to Acer, Fraxinus, Prunus and Quercus plant material.

\begin{tabular}{lccccc}
\hline & $\begin{array}{c}\text { Fresh weight } \\
\text { in mg }\end{array}$ & Species & $\begin{array}{c}\text { Leaves from in vitro } \\
\text { culture material }\end{array}$ & $\begin{array}{c}\text { Mature leaves from } \\
\text { the green house }\end{array}$ & $\begin{array}{c}\text { Mature leaves from } \\
\text { the field }\end{array}$ \\
\hline $\begin{array}{l}\text { SNAP-O-SOL } \\
\text { (Biotexc, USA) }\end{array}$ & 100 & Q, F & 0 & 0 & NA \\
$\begin{array}{l}\text { DNA Isolator } \\
\text { (Genosys, UK) }\end{array}$ & 100 & Q, F & 0 & 0 & NA \\
$\begin{array}{l}\text { XTRACT } \\
\text { (AMS Biotech.) }\end{array}$ & 100 & Q, F & 0 & NA \\
$\begin{array}{l}\text { NUCL. PHYT. } \\
\text { (Scot Lab, UK) }\end{array}$ & 100 & Q, F, P, A & $200-300 \mu \mathrm{g} \mathrm{g}^{-1} \mathrm{FW}$ & degraded DNA & degraded DNA \\
$\begin{array}{l}\text { SUL and Korban } \\
\text { (1996) }\end{array}$ & 100 & Q, F, P, A & $200-400 \mu \mathrm{g} \mathrm{g}^{-1} \mathrm{FW}$ & degraded DNA & degraded DNA \\
$\begin{array}{l}\text { Graham et al. (1994) } \\
\begin{array}{l}\text { Lefort and Douglas } \\
\text { (this article) }\end{array}\end{array}$ & 500 & Q, P & $1-10 \mu \mathrm{g} \mathrm{g}^{-1} \mathrm{FW}$ & $1-10 \mu \mathrm{g} \mathrm{g}^{-1} \mathrm{FW}$ & NA \\
\hline
\end{tabular}

$\mathrm{Q}=$ Quercus, $\mathrm{F}=$ Fraxinus, $\mathrm{P}=$ Prunus, $\mathrm{A}=$ Acer, $\mathrm{NA}=$ non analysed .

Acknowledgements: Dr Francois Lefort was supported by European Union FAIR contract N(CT 965004. We acknowledge Dr Rejane Streiff from the Laboratory of Genetic Improvement of Trees, Inra Cestas, Bordeaux, France, for her help in analysing microsatellite profiles.

\section{REFERENCES}

[1] Chen D.M., de Filippis L.M., Application of genomic DNA and RAPD-PCR in genetic analysis and fingerprinting of various species of woody trees, Austr. For. 59 (1996) 46-55.

[2] Doyle J.J., Doyle J.L., A rapid DNA isolation procedure for small quantities of leaf tissue, Phytochem. Bull. 19 (1987) $11-15$.

[3] Graham J., Mc Nicol R., Greig K., van der Ven V., Identification of red raspberry cultivars and an assessment of their relatedness using fingerprints produced by random primers, J. Hort. Sci. 69 (1994) 123-130.

[4] Howland D.E., Oliver R.P., Davy A.J., A method of extraction of DNA from birch, Plant Molec. Biol. Report 9 (1991) $340-344$.

[5] Lefort F., Douglas G.C., Occurrence and detection of triploid oaks by microsatellite analysis, in: Douglas G.C, Lefort F. (Eds.), Strategies for Improvement of Forest Species. Proceedings of the Teagasc / TCD Symposium On Forest Genetics, COFORD, Dublin, 1998, in press.
[6] Lefort F., Edwards K., Douglas G.C., Identification of microsatellite regions of ash Fraxinus excelsior, Dendrome 4 (1997) 4.

[7] Milligan, B.G., Plant DNA isolation, in: Hoexel A.R., (Ed.), Molecular Genetic Analysis of Populations. A Practical Approach. The Practical Approach Series, IRL Press, Oxford University Press, Oxford, UK, pp. 59-88, 1992.

[8] Murray M.G., Thompson W.F., Rapid isolation of high molecular weight plant DNA, Nucleic Acids Res. 8 (1980) $4321-4325$.

[9] Steinkellner H., Fluch S., Turetschek E., Lexer C., Streiff R., Kremer A., Burg K., Glössl J., Identification and characterization of (GA/CT)n-microsatellite loci from Quercus Petraea, Plant Molec. Biol. 33 (1997) 1093-1096.

[10] Streiff R., Lefort F., A protocol for higher contrasted DNA silver staining, CastAway Times 6 (1997) 2.

[11] Stewart N., Via L., A rapid CTAB DNA isolation technique useful for fingerprinting and other PCR applications, BioTechniques 14 (1993) 748-749.

[12] Sul I.W., Korban S.S., A highly efficient method for isolating genomic DNA from plant tissues, Plant Tissue Cult. Biotech. 2 (1996) 113-116.

[13] Wagner D.B., Furnier G.R., Saghai-Maroof M.A., Williams S.M., Dancik B.P., Allard R.W., Chloroplast DNA polymorphisms in lodgepole and jack pines and their hybrids, Proc. Nat. Acad. Sci. USA 84 (1987) 2097-21. 